Research

\title{
Adaptive Comanagement and Its Relationship to Environmental Governance
}

Ryan Plummer $^{1,2}$, Derek R. Armitage ${ }^{3}$ and Rob C. de Loë ${ }^{3}$

\begin{abstract}
We provide a systematic review of the adaptive comanagement (ACM) literature to (i) investigate how the concept of governance is considered and (ii) examine what insights ACM offers with reference to six key concerns in environmental governance literature: accountability and legitimacy; actors and roles; fit, interplay, and scale; adaptiveness, flexibility, and learning; evaluation and monitoring; and, knowledge. Findings from the systematic review uncover a complicated relationship with evidence of conceptual closeness as well as relational ambiguities. The findings also reveal several specific contributions from the ACM literature to each of the six key environmental governance concerns, including applied strategies for sharing power and responsibility and value of systems approaches in understanding problems of fit. More broadly, the research suggests a dissolving or fuzzy boundary between ACM and governance, with implications for understanding emerging approaches to navigate social-ecological system change. Future research opportunities may be found at the confluence of ACM and environmental governance scholarship, such as identifying ways to build adaptive capacity and encouraging the development of more flexible governance arrangements.
\end{abstract}

Key Words: adaptive comanagement; adaptive governance; environmental governance; integrated management; multilevel governance; resilience; systematic review

\section{INTRODUCTION}

Social-ecological resilience emphasizes the interdependence of people and nature (Berkes and Folke 1998, Berkes et al. 2003), and refers to the amount of change a social-ecological system can undergo while maintaining structure and function; the capability for self-organization; and the extent to which the capability for learning and adaptation and transformation can be built and enhanced (Carpenter et al. 2001, Folke 2006). Building social-ecological resilience and sustaining adaptive capacity, the ability to be robust to disturbances and adapt to new situations, actual or anticipated changes, while keeping open future options, is critical to addressing change for sustainability (Folke et al. 2002, Berkes et al. 2003, Plummer and Armitage 2010).

Approaches to navigating the dynamics of social-ecological systems are a growing area of scholarship and practice. These approaches typically emphasize collaboration, learning, and building adaptive capacity (Folke, et al. 2002, Folke et al. 2005, Plummer and Armitage 2010). Examples of these approaches in practice are increasingly common as resource users, managers, and communities endeavor to deal with change. They can be seen in Arctic comanagement arrangements where efforts to bridge knowledge systems are linked to shared decision making about resources, e.g., harvest levels (Armitage et al. 2011), in the Murray-Darling Basin in the creation of water markets and expansion of planning roles to address changes in water availability (de Loë and Bjornlund 2010), and in South Africa where collaborative efforts have emerged to resolve profound livelihood challenges in social- ecological systems that have changed dramatically in a very short period of time (Fabricius and Cundill 2010).

Multiple terms characterize these approaches. Examples include resilience management, interactive governance, transition management, collaborative governance, adaptive governance, and adaptive comanagement. However, we are concerned principally with an association that is routinely and often ambiguously made between governance and adaptive comanagement (ACM). For example, ACM is frequently described as an approach or strategy for the governance of social-ecological systems in the face of complexity and uncertainty (Carlsson and Berkes 2005, Armitage et al. 2009, Kofinas 2009, Plummer 2009, Cundill and Fabricius 2010). Conversely, "good" governance, in other words, governance that is characterized by polycentric institutions, legitimacy and transparency, empowerment and social justice, diversity of participating actors, and where multilevel institutions are matched with social-ecological dynamics (Lebel et al. 2006, Lockwood et al. 2010), also is identified as characteristic of ACM (Olsson et al. 2004a, Folke et al. 2005, Berkes 2007, Berkes 2009).

Despite these interrelationships, the concepts of governance and ACM have different intellectual and disciplinary foundations. Governance perspectives draw broadly on literature from political science and international relations, and are applied in a wide range of contexts, including global governance, corporate governance, organizational governance, information technology governance, nonprofit governance, 
project governance, and public administration. More recently, governance concerns have become prominent in the context of the environment. Governance here is broadly understood as the exercise of authority over the environment through the processes and institutions by which decisions are made (World Resources Institute 2003). In contrast, adaptive comanagement reflects a stronger "systems" perspective (Berkes and Folke 1998). This literature draws on insights from the field of common property and critical perspectives on comanagement (McCay and Acheson 1987, Pinkerton 1989, Ostrom et al. 2002), and is informed by ideas from the learning (experimental and experiential) aspect of adaptive management (Walters 1986, Lee 1993) to engender a distinct and novel approach (Berkes et al. 2007; see Plummer et al. 2012). In the frequently cited definition by Folke et al. (2002:20), ACM is "a process by which institutional arrangements and ecological knowledge are tested and revised in a dynamic, ongoing, self-organized process of learning-bydoing."

Our research is positioned in relation to the emerging approaches to navigate the dynamics of social-ecological systems. It investigates (1) how the ACM literature considers governance and (2) what insights the ACM literature has for core environmental governance challenges.

\section{KEY CHALLENGES IN ENVIRONMENTAL GOVERNANCE}

Governance, of all types, is concerned with goal-oriented, deliberative interventions in society (Kooiman 1993). It involves the common elements of (1) a relationship between objects and subjects, (2) a desire to realize change in that relationship, and (3) the conceptualizations of the context in which it is embedded (Glasbergen 1998). All ideas and concepts of governance take a position on these elements as they bring together normative considerations of what should be, and empirical observations that form the basis of what could be (Glasbergen 1998).

The normative dimension of environmental governance is typically framed as sustainability (Hempel 1996, Adger et al. 2003, Folke et al. 2005). Gibson et al. (2005) specifically identify the idea of 'sustainable development' as put forth by the World Commission on Environment and Development (1987), as being embraced by governance bodies across a broad range of jurisdictions. In some instances, however, the definition of governance is applied to an aspect of the environment. For example, Kooiman and Bavinck (2005:17) define governance in the context of their work on fisheries as "... the whole of public as well as private interactions taken to solve societal problems and create societal opportunities" and including " $\ldots$ the formulation and application of principles guiding those interactions and care for institutions that enable them." Others define environmental governance more broadly. Paavola (2007:97), for example, asserts that "environmental governance should be understood broadly so as to include all institutional solutions for resolving conflicts over environmental resources." Similarly, Lemos and Agrawal (2006:298) suggest that "environmental governance refers to the set of regulatory processes, mechanisms and organizations through which political actors influence environmental actions and outcomes."

Numerous models for environment governance exist that set out how and why change should occur. In his foundational work on environmental governance, Glasbergen (1998) identifies and describes five main models. These include: regulatory, market regulation, civil society, co-operative, contextual control, and self-regulation. Meadowcroft (1998) notes the idealized nature of these models and stresses that they are not mutually exclusive and in reality often work together. Lemos and Agrawal (2006) illustrate the phenomenon of conventional mechanisms and strategies of governance giving way to hybridization as they position idealized forms, i.e., state, market, and community, in relation to more nuanced ones, i.e., comanagement, public-private partnerships, private social partnerships. The degree of potential hybridization and lack of simple models of environmental governance suggests the possibility of a wide range of governance forms. Drawing on this perspective, de Loë et al. (2009) argue that environmental governance is thus dynamic and constantly being reconfigured.

Despite the breadth of perspectives that exist, it is possible to identify in the environmental governance literature a series of common concerns or challenges. Lemos and Agrawal (2006), for example, point to the importance of accountability as governance increasingly involves nonstate actors. Paavola (2007) argues for inclusive approaches that focus on institutional design solutions. Duit and Galaz (2008) employ a complex adaptive systems perspective on governance to illuminate the previously overlooked issues of how forms of governance should be evaluated, effects of cross-scale interactions, and how governance systems respond to changes. Lockwood et al. (2010) identify eight issues for which they assembled a series of principles for natural resource governance. These include: legitimacy, transparency, accountability, inclusiveness, fairness, integration, capability, and adaptability. The Earth Systems Governance project (see Biermann et al. 2009) highlights five governance research themes or challenges, including architecture or institutional design and arrangements, the agency, i.e., role and influence, of state and nonstate actors, the adaptiveness of governance mechanisms and processes, as well as issues of accountability, legitimacy, and allocation, e.g., of resources. To this set of challenges, Biermann et al. (2009) highlight four "crosscutting" themes necessary for integrated understanding, including the role of power, knowledge, norms, and the issue of scale. Using a synthesis of common environmental governance challenges, de Loë et al. (2009) explore how different models can work together to address issues of water 
Table 1. Core environmental governance issues or challenges (adapted from Armitage et al. 2012)

\begin{tabular}{|c|c|}
\hline $\begin{array}{l}\text { Core issue } \\
\text { or challenge }\end{array}$ & Description \\
\hline $\begin{array}{l}\text { Accountability } \\
\text { and legitimacy }\end{array}$ & $\begin{array}{l}\text { Accountability concerns the responsible exercise of power (through standards and systems) as entities } \\
\text { (individuals, organizations, agencies) acknowledge and assume responsibilities of actions and determine } \\
\text { outcomes. Legitimacy involves the power to influence others and approval of an institution or actor by } \\
\text { an entity subject to its actions, encompassing procedural (how decisions are made) and substantive } \\
\text { (morals, values, beliefs) dimensions within a socially constructed context. Broadening accountability } \\
\text { and legitimacy from formal legal arrangements to reflect its pluralist forms and nonformal sources is } \\
\text { stressed. }\end{array}$ \\
\hline Actors and roles & $\begin{array}{l}\text { Governance, as opposed to government, emphasizes participation by diverse nonstate actors in decision } \\
\text { making and prompts a range of potential roles for all actors. Role ambiguity is a concern and } \\
\text { redundancy and layering of roles is beneficial in light of uncertainty. Incentivizing participation, a } \\
\text { supportive policy framework, and connecting individuals/organizations are salient considerations. }\end{array}$ \\
\hline $\begin{array}{l}\text { Fit, interplay, } \\
\text { and scale }\end{array}$ & $\begin{array}{l}\text { The interconnected and nested nature of social-ecological systems is paramount. Arrangements need to } \\
\text { reflect the scale of the environmental concern (e.g., spatial fit) as well as acknowledge/respond to the } \\
\text { dynamism of cross-scale and cross-level interactions (e.g., threshold behavior, cascading effects). } \\
\text { Multilevel arrangements that involve multiple linkages stress connections among actors in a networked } \\
\text { fashion. Although such arrangements confer adaptability and stability, they also may confront issues of } \\
\text { interplay, constrain integration, and be cumbersome. }\end{array}$ \\
\hline
\end{tabular}

Adaptiveness, flexibility, and learning

Evaluation and monitoring

Knowledge

\begin{abstract}
Adaptiveness responds to the uncertainty and change that characterize complex systems and catalyzes attention on fostering resilience and building adaptive capacity. Arrangements in structure and function need flexibility to counter uncertainty as well as platforms to learn from feedback. Learning takes place individually and collectively. It is a social process and outcome arrived at by the participation and interaction of diverse actors who learn by doing and modifying their actions based on feedback.

Evaluation is concerned with systematically assessing the value of the goal-oriented deliberative intervention in regard to a social-ecological system. Assessment and monitoring that is participatory, interactive, and multiscale are required. Extending evaluation parameters beyond easily observable process elements and outcomes is highlighted. Diagnostic approaches direct attention to identifying and monitoring critical variables. Selecting and matching appropriate indicators to the scale of assessments is a challenge.
\end{abstract}

Environmental governance requires an intense amount of diverse information. The value of multiple knowledge sources, diverse types of knowledge, and means to facilitate exchange are stressed. In going beyond amalgamating information, emphasis is placed on the coproduction of knowledge as generated collaboratively through the interactions of diverse actors. Accepting the dynamism and contingency of knowledge is a notable challenge.
Selected key references

Suchman 1995, Van

Kersbergen and Van Waarden 2004, Trachtenber and Focht 2005, Tyler 2006, Paavola 2007, Beisheim and Dingwerth 2008, Ballesteros et al. 2010

Singleton 2002, Dietz et al. 2003, Savan et al. 2004, Ansell and Gash 2008

Gibson et al. 2000, Ostrom et al. 2002, Dietz et al. 2003, Cash et al. 2006, Moss 2007, Pahl-Wostel et al. 2008,

Young et al. 2008

Lee 1993, Folke et al. 2002, Westley 2002, Folke et al. 2005, Armitage 2008, Armitage et al. 2008, Biermann and Pattberg 2008

Bellamy et al. 2001, Conley and Moote 2003, Garaway and Arthur 2004, Ostrom 2007, Plummer and Armitage 2007

Cortner 2000, Kates et al. 2001, Clark 2001, Bäckstrand 2003, Hahn et al. 2006, Blackstock and Carter 2007, Berkes 2009 governance in the Murray-Darling Basin of Australia. Their findings suggest that strengthening governance in advance of a crisis is critical because the water situation in the MurrayDarling Basin illustrates the possibility that reforms may be inadequate even with attention to issues such as accountability and legitimacy, actor involvement, fit, knowledge generation, adaptiveness, and evaluation.

We draw on these syntheses of governance challenges as a way to frame our systematic review. Table 1 identifies and describes six core issues or challenges. We do not claim these issues reflect an idealized typology, but rather view the synthesis as a useful way to frame our analysis.

\section{METHODS}

A systematic literature review "... strives to comprehensively identify, appraise, and synthesize all the relevant studies on a given topic" (Petticrew and Roberts 2006:19). Historically, systematic reviews have been quantitative in orientation, although their application in qualitative research is becoming more common (Dixon-Woods et al. 2006, Hughes et al. 2009, O'Connell and Downe 2009). Systematic review methods are firmly rooted in evidenced-based health care (Green 2005, Dixon-Woods et al. 2006), but are increasingly being applied to subjects across both the natural and social sciences. Further details on the approach applied in this paper are outlined in Plummer et al. (2012).

The systematic review used in this analysis of ACM involved five steps, including question definition, study and search protocol, search and screen results, analysis, and presentation of results. With regard to the first step, our analysis was framed by the following two questions: (1) how does the ACM literature consider governance and (2) what insight does the ACM literature have for core environmental governance challenges? 
The study and search protocol sought to maximize the amount of information returned by using the search terms 'ecosystem' or 'ecolog' or 'environment' and 'adaptive co-management' or 'adaptive comanagement' or 'adaptive co management' or 'adaptive collaborative management.' The temporal period covered was from 1997 (first appearance of the concept of ACM in the published literature) to May 2010. The search for literature encompassed both peer-reviewed and nonpeer reviewed literature. The 414 potential citations revealed were screened by reading the title, abstract, and key words. Many potential citations (298) were excluded for falling outside the criteria of date, language (written in English), and topic (ACM and environment, natural resources, and/or social-ecological systems). The remainder of the items were retrieved and read to ensure they met the aforementioned criteria, with 108 items eventually being organized into a QSR NVIVO database. Detailed stepwise procedures to arrive at the 108 items used in this study are given by Plummer et al. 2012 .

The analysis occurred using an adapted grounded theory approach (Thorne et al. 2004, O'Connell and Downe 2009). A coding system was used to affix descriptive labels to passages of text and then group similar passages together with iterative passes through each of the 108 literature items. In the first pass of coding we identified all passages in which the term "governance" was explicit, excluding mention in the list of references. Although we acknowledge the limitations of this approach, as opposed to also including the implied use, we chose to initially limit the investigation to the explicit use of the term because of the range of definitions and employment. Axial coding was then used to revisit each of the passages identified and to group similar ideas together into themes. In this way themes emerged about how people writing in the ACM literature consider governance. In line with the question driving the analysis, open coding was initially employed to code for passages that explicitly or implicitly related to the six key concerns from the environmental governance literature described in Table 1. Axial coding was then used to distinguish patterns among the passages within each of the categories and to group them into themes. These emergent themes are the core of our results and are described in terms of the concept represented. Illustrative examples from systematic literature review are also provided.

\section{RESULTS}

\section{How does the ACM literature consider governance?}

The entry point of analysis was to see how people writing in the ACM literature consider governance by coding each explicit occurrence and the accompanying passage. A total of 1948 explicit occurrences of the term governance appeared in the 108 items analyzed. Seventy-seven of the 108 items (71\%) contained a minimum of one occurrence of the term governance. The number of occurrences per item ranged from a minimum of zero to a maximum of 358 in a doctoral dissertation. All of the passages surrounding the term governance were then analyzed and those involving similar concepts were grouped together in a theme. The theme with the highest frequency explicitly contained the term governance, but did not explicitly contain the term ACM.

The terms governance and ACM appeared together in 290 passages in 55 items. Passages containing both terms were analyzed for similar connotations and grouped. Table 2 identifies and describes the themes resulting from the analysis. In the body of literature examined where both terms appear, ACM was most frequently understood as a mechanism, i.e., model, approach, strategy, method, system, tool, for making governance operational. For example, Folke et al (2005:448-449) offered the following statement.

Adaptive comanagement relies on the collaboration
of a diverse set of stakeholders, operating at different
levels, often through networks from local users to
municipalities, to regional and national organizations,
and also to international bodies. The sharing of
management power and responsibility may involve
multiple institutional linkages among user groups
or communities, government agencies, and
nongovernmental organizations (NGOs). In
addition, adaptive comanagement extends adaptive
management into the social domain and is a way to
operationalize adaptive governance. Although
adaptive management focuses on understanding
ecosystem dynamics and feeding ecological
knowledge into management organizations, adaptive
governance conveys multi-objective reality when
handling conflicts among diverse stakeholders and,
at the same time, adapts this social problem to
resolve issues concerning dynamic ecosystems.

Additional themes emerging from the analysis reinforce the close functional relationship between ACM and governance. In the broadest sense, the 'enabling' theme suggests that governance facilitates ACM. The following themes emerging from the ACM literature add specificity as to how this occurs. For example, adaptive governance is, or ought to be, an objective of ACM. 'Good' governance contributes to successful ACM and both are enhanced by features such as learning, social capital, communication, etc. ACM requires multilevel governance that is polycentric and peoplecentered.

Although the themes in Table 2 signal closeness between the two concepts, they also convey the sometimes unbounded nature of the relationship. Examples of these themes from the $\mathrm{ACM}$ literature include: $\mathrm{ACM}$ is considered as governance or as analogs; ACM and governance are explicitly present in capturing an approach to environment/resource management; and 'good' governance is a 'face' of ACM. 
Table 2. Thematic analysis of passages with the explicit terms governance and ACM.

\begin{tabular}{|c|c|c|c|}
\hline Theme & Description & $\begin{array}{l}\# \text { of } \\
\text { Items }\end{array}$ & $\begin{array}{c}\text { \# of } \\
\text { Passages }\end{array}$ \\
\hline $\mathrm{ACM}$ as governance & $\mathrm{ACM}$ and governance are analogs. & 9 & 22 \\
\hline Shift in governance & $\mathrm{ACM}$ is situated in the context of the transition from government to governance. & 1 & 1 \\
\hline $\begin{array}{l}\text { Making governance } \\
\text { operational }\end{array}$ & $\begin{array}{l}\text { ACM is a way to make governance operational and is a model, approach, strategy, method, system, or tool } \\
\text { for governance. }\end{array}$ & 26 & 53 \\
\hline Defining terminology & $\begin{array}{l}\text { ACM and governance are explicitly present in capturing the essence of an approach to environment/ } \\
\text { resource management. }\end{array}$ & 8 & 10 \\
\hline $\begin{array}{l}\text { ACM and good } \\
\text { governance }\end{array}$ & Good governance is connected to ACM and represents a 'face' of ACM. & 6 & 13 \\
\hline Adaptive governance & $\begin{array}{l}\text { Adaptive governance enables ACM, is an objective of ACM, and/or represents the social dimension of } \\
\text { ACM when examining ecosystems and landscapes. }\end{array}$ & 15 & 28 \\
\hline $\begin{array}{l}\text { Multilevel } \\
\text { governance }\end{array}$ & $\begin{array}{l}\text { ACM stresses multilevel linkages and governance. Successful ACM requires polycentric, multilevel, } \\
\text { people-centered, or participatory governance. }\end{array}$ & 19 & 32 \\
\hline Linkages & $\begin{array}{l}\text { Governance and ACM are, or should be, closely connected. ACM acts as a bridge to connect governance } \\
\text { with complex systems. }\end{array}$ & 7 & 9 \\
\hline Enabling & Governance enables ACM. & 2 & 3 \\
\hline $\begin{array}{l}\text { Features to enhance } \\
\text { success }\end{array}$ & $\begin{array}{l}\text { 'Good' governance contributes to successful ACM. Governance and ACM are similarly enhanced by: } \\
\text { (social) learning, trust building, institutional development, conflict resolution, empowerment, local } \\
\text { stewardship involvement, social capital, nonstate actors, communication, power/empowerment, and/or } \\
\text { decentralization. }\end{array}$ & 18 & 32 \\
\hline $\begin{array}{l}\text { Calls for further } \\
\text { investigation }\end{array}$ & $\begin{array}{l}\text { ACM and governance require further investigation empirically, theoretically, and/or practically. } \\
\text { Governance and ACM have not been studied deeply enough. }\end{array}$ & 5 & 7 \\
\hline Common challenges & $\begin{array}{l}\text { ACM and governance are confronted with common challenges of politics, power sharing, policy } \\
\text { experiments, and collaboration. ACM approaches can sometimes undermine local governance. }\end{array}$ & 6 & 7 \\
\hline $\begin{array}{l}\text { ACM is not a } \\
\text { governance panacea }\end{array}$ & $\begin{array}{l}\text { ACM has the potential to fail as an approach to governance and depends upon the inclusion of key } \\
\text { features and factors. Therefore, ACM is not a governance panacea. }\end{array}$ & 7 & 11 \\
\hline No relationship given & ACM and governance are mentioned in the same passage, but are not related to each other specifically. & 18 & 41 \\
\hline Case studies & Case studies and examples that address ACM and governance. & 15 & 21 \\
\hline Total & & 55 & 290 \\
\hline
\end{tabular}

\section{What insight does the ACM literature have for key environmental governance challenges?}

The main intent of this research was to gain insights about how the ACM literature addresses specific issues or challenges in the environmental governance literature. The extent to which each governance concern identified in Table 1 appears in the ACM literature is illustrated in Figure 1. The results that follow highlight contributions or insights of ACM scholarship to each of the six environmental governance challenges described earlier in the paper.

\section{Accountability and legitimacy}

Considerable discourse in the environmental governance literature relates to the concepts of accountability and legitimacy. Although Table 1 offers a description of these specific issues, it is important to acknowledge the complexity associated with each concept. As illustrated in Figure 1, the category of accountability and legitimacy was identified in 28 items and 46 passages within the ACM literature. Three specific themes emerged from the analysis. Passages grouped into the first theme identify the ACM process as involving accountability or producing accountability. The need for managers to accept the consequences of their decisions and for those involved in the ACM process to collectively share responsibility in a transparent manner are stressed.
Fig. 1. The appearance of key governance concerns in the ACM literature.

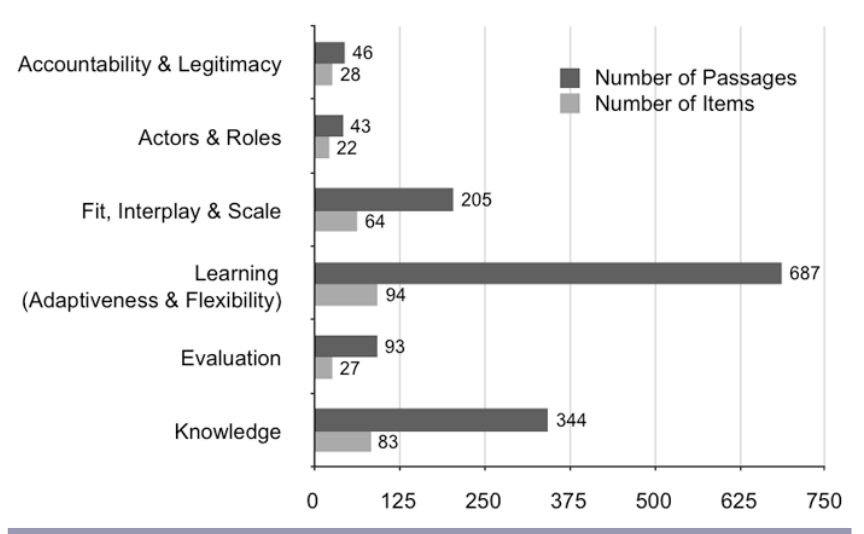

The second theme specifically addresses the matter of legitimacy. Passages within this theme describe the manner in which legitimacy (i) is enhanced through the diversity of actors involved; (ii) assists with the coordination of information and initiation of collaborations; and (iii) results in greater compliance with rules/institutions. Olsson et al. (2004b) 
convey how this came about in the case of the Ecomuseum Kristianstads Vattenrike.

\begin{abstract}
Incorporating the EKV as an organization within the Municipality of Kristianstad created space for self-organization and development of social networks across scales for ecosystem management. The legitimacy of municipal supportmade it possible to coordinate information and start collaborative processes that we argue are necessary for ecosystem management, yet allowed the EKV to maintain the flexibility of a semiautonomous organization.
\end{abstract}

The third theme encompasses passages that focus on the connection between accountability and legitimacy in relation to ACM. A common insight from the passages in this theme is that the state can establish or enhance legitimacy and accountability of the new or modified institutional arrangements through legislative supports or enabling policy environments. Work drawing upon case study examples in Macubeni, Nqabara, Makuleke, and Richtersveld by Fabricius and Collins (2007:92-93) is indicative of this theme.

It is therefore essential to invest heavily in the development of functioning and resilient governance systems in the early stages of projects, before conflict becomes a real problem and the obstacles listed above have surfaced. Many of these obstacles can be overcome by focusing on the following aspects of governance: ...

3. Clearly defined and legitimised conflict resolution procedures, including acknowledged arbitrators and facilitators (Ostrom, 1990).

4. Legitimacy and acceptance of the governance structure by community members, traditional authorities, elected political representatives, municipal officials, and managers in provincial and national government (DEAT, 2003).

5. Formal commitment to well-defined roles and responsibilities by key individuals in the network. These responsibilities should be endorsed by supervisors and committed to in writing by key individuals, and they should be held accountable for failures to meet their commitments.

\section{Actors and roles}

Encouraging a diversity of actors, as opposed to just staff from government agencies, to come together and take on various roles to address a common problem or interest is a core environment governance challenge. Several themes emerged to convey the degree to which ACM literature addresses this concern of environmental governance. Passages in the database often contained multiple concepts associated with actors and their roles. In interpreting these results, it is important to note that the items and passages are not mutually exclusive to a theme. Passages expressing the importance of a diversity of actors for filling a variety of roles in the ACM process were grouped together under the label "importance of diverse actors for filling general roles." Passages in this theme explicitly asserted the need to involve diverse actors in ACM and also provided illustrative examples. For instance, Garaway and Arthur (2004:26) write that "a range of stakeholder groups, including researchers, extension workers and resource users (who may not usually work together), need to be identified and join forces in a process where learning is combined with management".

Additional themes draw attention to specific reasons for involving an array of actors in ACM and underscore particularly important roles. Within the theme of "sharing power" several subthemes emerged that draw specific attention to empowerment, devolution of power/ decentralization, and the meaningful involvement of actors not conventionally engaged with decision making and management. As a complement, the theme of "sharing responsibility" emphasizes extending answerability to more actors, who are connected horizontally and vertically. Additionally, the theme of "incentives" specifically addresses the issue of incentivizing actors to participate in ACM with monetary and nonmonetary lures as well as nonmonetary rewards once a commitment is fulfilled.

The ACM literature also contributes insights to the challenge of actors and roles by drawing attention to key functions of individuals and organizations. The first theme in this regard emphasizes the importance of leadership to the success of ACM processes, or failure of the process in its absence. A leader within this theme may be an individual, group, or organization and how leadership contributes to several aspects of ACM are documented. A second theme highlights the role of groups of actors as critical intermediaries in ACM, referred to as bridging organizations, boundary organizations, or brokering organizations. These actor groups play a catalytic role in fostering vertical and horizontal linkages and interactions as well as facilitating group processes such as communication, knowledge coproduction, and conflict resolution. The following passage from Berkes (2009:1695) illustrates the role of these actors.

The bridging organization in the Swedish Millennium Ecosystem Assessment case of Kristianstads Vattenrike Biosphere Reserve was a municipal organization, the Ecomuseum Kristianstads Vattenrike $(E K V)$, later becoming the biosphere office. The EKV provided the forum for trust building, conflict resolution, and accessing knowledge. For example, when the wetland area in Vattenrike was set aside for conservation purposes, 
it became overgrown after the halting of grazing. The EKV coordinated the deliberation over this unintended impact of conservation, leading to the coproduction of new knowledge ... By linking networks concerned with different objectives (bird conservation, water quality, cultural heritage), the EKV provided leadership to produce a comprehensive vision and goals ...

\section{Fit, interplay, and scale}

Environmental governance scholars are often concerned with the interplay and interactions of institutions at levels and across scales as well as the fit between social and biophysical systems (Young et al. 2008). As illustrated in Figure 1, considerable evidence is present in the ACM literature that directly addresses this particular concern.

Analysis of the ACM literature reveals a concerted focus on the linkages/interactions among organizations. Passages grouped into an initial theme address the importance of linkages and interactions among organizations, but do not specify the nature of these connections. Passages grouped into a second theme explicitly mention cross scale and/or cross level interactions, but do not elaborate upon these concepts. Additionally, several themes emerged that unpack aspects of the interactions/linkages as being horizontal (between/among entities at one level) and/or vertical (between/among entities at other levels). These include themes that address both horizontal and vertical, specifically vertical, and specifically horizontal.

Reference to addressing the notion of fit between institutional arrangements and biophysical systems emerged as a specific theme within the ACM literature. Within this theme, emphasis is placed on how ACM is a flexible approach tailored to specific places and situations. The dynamic orientation of $\mathrm{ACM}$ and the manner in which its features, e.g., linkages across levels, bridging organizations, leadership, create conditions that enhance fit. Illustrative of this theme is the following passage by Galaz et al. (2006:5):

One discussed strategy to enhance the fit between ecosystems and governance is adaptive comanagement. Adaptive co-management refers to the multilevel and cross-organizational management of ecosystems. Such multilevel governance systems often emerge to deal with crisis, and can develop within a decade ...

\section{Adaptiveness, flexibility, and learning}

In the face of uncertainty and complexity, a major concern of environmental governance is the ability to intentionally learn through change and adapt (sensu adaptive management) using experimental and experiential approaches. Learning is a core feature of ACM and as a reflection of its centrality this environmental governance concern is addressed extensively (Fig. 1). The ideas of adaptiveness, flexibility, and learning are commonly grouped together in the ACM literature and in this theme passages generally make reference to learning as a variable or component of ACM.

The passage by Cundill and Fabricius (2010) is illustrative of the attention given to this environmental governance issues within the ACM literature as they write:
Adaptive co-management is increasingly seen as a governance-based approach to managing complex adaptive systems ... The approach is expected to achieve this by marrying the strengths of adaptive and collaborative (co-) management through afocus on adaptive learning and linkages between actors and organizations operating at multiple levels ...

Although the ACM literature generally addresses adaptiveness, flexibility, and learning, the body of work on the latter is particularly noteworthy. The analysis of the ACM literature reveals the following substantial subthemes on the concept of learning.

- Social learning involves shared learning among individuals through an iterative process of engagement and reflection. It is frequently characterized according to the correcting of routine errors (single loop), adjustment of policies and values (double loop), and fundamental changes to governance norms and protocols (triple loop).

- Experiential learning emphasizes learning by doing. It starts with actual experience and fosters change through stages of reflection, abstraction, and experimentation.

- Transformative learning highlights reflective processes by which perceptions and consciousness are altered. Individuals engage in task-oriented problem-solving as well as critical examination of intentions to bring about change.

Insights into the environmental governance concern of adaptiveness, flexibility, and learning from the ACM literature stem from the considerable practical experiences as conveyed in detailed case study descriptions with this focus (e.g., Garaway and Arthur 2004, Plummer and FitzGibbon 2007, Wollenberg et al. 2007, Cundill 2010). Conceptually unpacking the concept of learning, identifying its paradoxical employment, and advancing its understanding (e.g., McDougall 2001, Armitage et al. 2008, Berkes 2009) are valuable contributions in relation to this environmental concern.

\section{Evaluation and monitoring}

The specific terms "evaluation" and/or "monitoring" are often explicitly employed in definitions of ACM. ACM is frequently 
described as a mechanism or strategy to develop and/or implement goal oriented deliberative intervention in reference to a specific system, situation, and/or place. As illustrated in Figure 1, information addressing the concern of evaluation and monitoring were identified in 27 items and 93 passages. The following passage by the Center for International Forestry Research (Fisher et al. 2007:30) is illustrative of this theme.

... the purpose of monitoring in an ACM approach is to continuously generate a better understanding of system behavior and to facilitate learning about how to manage it better. The ACM model hypothesizes that a collaborative monitoring approach, which uses iteratively and jointly developed and tested local indicators, will be more effective in addressing this challenge than conventional approaches to monitoring in many contexts. Not only do such types of monitoring systems incorporate diverse mental models, but they also focus on critical processes as well as the outcomes or impacts of these processes, as understood and defined by the local stakeholders

The ACM literature identifies monitoring and evaluation as a challenge to scholarship and practice because of missing requisite information and knowledge, lack of measures and criteria, and complications due to issues of complexity and scale. It contributes to addressing this challenge by offering organizational devices/visual aids to assist researchers and managers. For example, Plummer and Armitage (2007) recast evaluation in natural resources management in light of complex adaptive systems thinking. A resilience-based framework is offered to evaluate ACM that draws attention to components of ecosystem conditions, livelihood outcomes, and process and institutional situations. The utility of existing or modified evaluation and monitoring frameworks to a case of ACM are also assessed. For example, Muñoz-Erickson et al. (2010) assess the holistic ecosystem health indicator framework as an evaluative tool using the case of the Diablo Trust in Arizona.

The ACM literature also contributes by communicating findings from experiences with monitoring and evaluation. For example, Cundill and Fabricius (2010) identify both system attributes and variables that could form the basis for monitoring the governance dimension of ACM and test a methodology for collaborative monitoring in four locations in South Africa. The following conclusion from Cundill and Fabricius (2010) reflects upon some of the lessons gained from their research with transferability more broadly.

The collaborative monitoring system that we tested provided a means to share state-of-the-art theory and best-practice insights about adaptive comanagement directly with community decisionmaking bodies, government officials, and donors.
The conceptual approach that informed this monitoring system, which included system attributes, key variables, and outcome indicators, provided the conceptual space to create easily understood indicators that participants could identify with while at the same time allowing the researcher to test the conceptual underpinnings of adaptive co-management. The approach was less effective in capturing multi-scale changes or in adapting to the tempo of change in key variables. This undermined the ability of monitoring activities to proactively predict forthcoming crises. Identifying and testing innovative methods to capture multi-scale changes in governance is an important area for future research.

Knowledge

Knowledge (sources, types, and processes) and knowledge generation are key concerns in the environmental governance literature (Biermann et al. 2009). The ACM literature addresses the concern of knowledge in 83 items and 344 passages, as illustrated in Figure 1. In grouping the passages within this category, several themes emerge that reflect how the ACM literature intersects with knowledge issues. First, the ACM literature addresses the needbenefits of combining knowledge sources and types. This need to combine knowledge is referred to in terms of integration or synthesis of knowledge previously segregated and is identified as key feature of ACM. The combination of traditional and scientific knowledge is often highlighted. The following passage by Wyckhuys and O'Neil (2010:307) illustrates how ACM responds to the concern of knowledge:
Adaptive comanagement combines the ecological knowledge of farmers and scientists in mutual learning systems, drawing on both farmers' experience and scientists' knowledge ... Such [an] approach allows both farmers and scientists to gain a better understanding of the workings of local agroecosystems. Also, appreciating linkages between landscape-level components and small- scale maize fields could help generate IPM innovations, such as land management tactics to conserve natural enemies ... Such tactics can then provide a "win-win" scenario for sustainable agriculture and the sound management of natural resources.

The ACM literature contributes insights into addressing this challenge by drawing attention to experiences with combining specific types of knowledge. This includes traditional and local knowledge, scientific knowledge, tactic knowledge, i.e., intuitive knowledge that is not explicit and difficult to transfer, and knowledge of ecosystem dynamics. The importance of 
Table 3. Key insights from the ACM literature contributing to understanding/addressing core environmental governance issues or challenges.

\begin{tabular}{|c|c|}
\hline $\begin{array}{l}\text { Core environmental } \\
\text { governance issue or } \\
\text { challenge }\end{array}$ & Insights from the ACM literature \\
\hline $\begin{array}{l}\text { Accountability and } \\
\text { legitimacy }\end{array}$ & $\begin{array}{l}\text { - Accountability is embedded in the ACM process and generated as an outcome as responsibility is shared collectively in a } \\
\text { transparent manner by those involved and consequences are collectively accepted. } \\
\text { - Legitimacy in association with ACM is: enhanced by the involvement of diverse actors; assists with coordination of } \\
\text { information and in undertaking new collaborations; and encourages compliance. } \\
\text { - Enabling policy environments can establish/enhance legitimacy and accountability. }\end{array}$ \\
\hline Actors and roles & $\begin{array}{l}\text { - Involving diverse actors in filling a variety of roles is important because of sharing power and responsibility. } \\
\text { - Incentivizing participation is an important consideration. } \\
\text { - Leadership is a critical ingredient. } \\
\text { - Actors acting as intermediaries (bridging organizations, boundary organizations, brokering organizations) make key } \\
\text { connections and facilitate group processes. }\end{array}$ \\
\hline Fit, interplay, and scale & $\begin{array}{l}\text { - Linkages and interactions between individuals and/or organizations are important. } \\
\text { - Interactions may be cross scale and/or cross level and may forge horizontal and/or vertical connections. } \\
\text { - Flexibility and dynamism of ACM permits tailoring the process to a specific place/situation and thereby enhances fit. }\end{array}$ \\
\hline $\begin{array}{l}\text { Adaptiveness, flexibility, and } \\
\text { learning }\end{array}$ & $\begin{array}{l}\text { - Adaptiveness, flexibility, and learning are essential characteristics for processes to address uncertainty and change and can } \\
\text { effectively be married with collaboration. } \\
\text { - A rich collection of experiences with adaptiveness-, flexibility-, and learning-oriented processes in practice exist in the } \\
\text { ACM literature from which lessons can be gleaned. } \\
\text { - The concept of learning is complicated. Specificity is required in its employment and attention is required in terms of its } \\
\text { definition, expectations, underlying mechanisms, participants, and ethical issues. }\end{array}$ \\
\hline Evaluation and monitoring & $\begin{array}{l}\text { - Monitoring and evaluation is embedded in the ACM process because insights about the system are continuously generated } \\
\text { and adjustments are made based on feedback. } \\
\text { - The ACM literature offers frameworks and examples of assessments in practice for evaluation and monitoring. } \\
\text { - Rich experiences of undertaking collaborative monitoring and evaluation in ACM offer lessons in both developed and } \\
\text { developing contexts. }\end{array}$ \\
\hline Knowledge & $\begin{array}{l}\text { - Multiple sources of knowledge and various types of knowledge need to be combined. ACM offers a novel process by } \\
\text { which knowledge integration and coproduction may occur. } \\
\text { - Accessible information is critical to knowledge development processes and learning. } \\
\text { - Knowledge in the ACM literature makes connections to networks and systems, communication, and learning. }\end{array}$ \\
\hline
\end{tabular}

information, its availability, and relationship to knowledge development and learning are highlighted. The possibility of generating knowledge through ACM is highlighted, and often specifically expressed in relation to testing and revising ecological knowledge. For example, in one of the most frequently cited definitions of ACM, Folke et al. (2002:20) define ACM as "a process by which institutional arrangements and ecological knowledge are tested and revised in a dynamic, ongoing, self-organized process of trial-and-error ..." Finally, the role of knowledge in the ACM literature is often allied to related governance concerns such as networks and systems, communication, and learning.

\section{CONCLUSION}

Building social-ecological resilience and fostering adaptive capacity is critical to embrace change, and ultimately, foster sustainability. ACM is an emerging approach to navigate social-ecological system change, and like allied concepts, draws on a range of disciplinary perspectives. We undertook a systematic review of the ACM literature, specifically, to better understand its relationship with governance and environmental governance in particular. In that context, we assessed how ACM may contribute insights to address key challenges identified in the environmental governance literature.

The relationship between the ACM literature and the environmental governance literature is complicated. Our systematic review of the ACM literature revealed 1948 explicit occurrences of the term governance, with more than $70 \%$ of items containing at least one mention of the term. Understanding how the ACM literature considers governance comes from the qualitative thematic analysis in which the passages with both terms were examined. ACM is understood as an important mechanism to make governance operational and the analysis reveals their close functional relationship, and in many instances an unclear boundary between the concepts. This finding is consistent with work by Huitema et al. (2009) who found the existence of relational ambiguity between the concept of ACM and environmental governance.

A main intent of this research was to better understand how the ACM literature contributes to specific concerns raised in the environmental governance. The results section conveys the themes that emerged from the systematic review of the ACM literature. Table 3 highlights the empirical and theoretical contributions of ACM scholarship to environmental 
governance literature with regard to: actors and roles; fit, interplay, and scale; adaptiveness, flexibility, and learning; evaluation; and, knowledge.

Although the ACM literature offers insights into each of these issues and concerns, the extent of the contribution varies. For example, with regard to actors and roles, ACM draws upon its comanagement heritage to offer particular depth of insight and experience with applied strategies for sharing power and responsibility. Similarly, its system orientation and conceptual roots in adaptive management result in substantive contributions to the challenges of adaptiveness and learning as well as fit, interplay, and scale. On the other hand, ACM research and practice may be enriched by drawing upon allied bodies of scholarship that deepen understandings of, for example, tensions between adaptability and accountability/ legitimacy (Hahn 2011), and which enhance sensitivity to human agency and power relationships in ways that reflect important contributions from social theory (Nadasdy 2007).

More generally, the findings from this systematic review have implications for those engaged with new approaches for navigating social ecological systems, such as ACM, adaptive governance, and/or resilience management. A decade ago Ludwig (2001:758) declared "the era of management is over" and argued that "the management paradigm fails when confronted with complex problems where there are no clearly defined objectives and a plethora of mutually contradictory approaches, each of which is plausible in a particular frame of reference." This research illustrates how the boundaries between ACM and governance are dissolving and how in practice the actual concepts as they are applied are increasingly interchangeable. Indeed, Lemos and Agrawal (2006) observe a general shift in the landscape of environmental governance away from centralized control toward alternative or hybrid forms of governance that hinge on participation and involvement of citizens. ACM is a clear example of this hybrid approach. Lockwood et al. (2010) similarly argue that new governance arrangements are required to adequately address integration, coordination, and multiscale considerations, that is, principles that are typically associated with "integrated management" or "ecosystem-based management" approaches. ACM is the emergent archetype of this fuzzy boundary between governance and natural resources management. Recognition of the interchangeability of ACM and governance perspectives is important because it creates a productive space for the interdisciplinary scholarship required to foster sustainability. At the same time, it points to the limitations and value of definitional ambiguity, e.g., lack of shared understanding that can impede joint learning vs. rejection of artificial constraints, which may facilitate more open dialogue.

In building upon the connections established in this systematic review, several future opportunities are likely to be found at the confluence of ACM and environmental governance scholarship. Environmental governance is a shared research platform (Reed and Bruyneel 2010) and innovation in tackling associated challenges may be enhanced by extending the boundaries of governance theory, as illustrated by Duit and Galaz (2008), or with the direct collaboration of ACM and governance scholars, as called for by Huitema et al. (2009). Furthermore, Engle and Lemos (2010:4) observe that “... the makeup and relationships between governance components and mechanisms that may or may not contribute to adaptive capacity remain relatively unexplored empirically." ACM literature and ongoing efforts in the field provide a useful context to pursue knowledge about the relationship between components, mechanisms, and outcomes. Ultimately, there is a need to move away from overly structural or static perspectives of governance (Plummer and Armitage 2010) and to "... create governance that is able to "navigate" the dynamic nature of multilevel and interconnected socio-ecological systems ..." (Galaz et al. 2008:169). ACM may be advantageously positioned in this regard. As this research demonstrates, the growing ACM literature offers several insights of value to the wider scholarship on environmental governance. At the same time, scholars of ACM, and allied concepts like adaptive governance or resilience management, can productively draw on traditional governance scholarship and do more to better theorize power, accountability, and legitimacy.

Responses to this article can be read online at: http://www.ecologyandsociety.org/issues/responses. $\mathrm{php} / 5383$

\section{Acknowledgments:}

The authors gratefully acknowledge the common dataset upon which this paper is based and we specifically thank our team members in that project - Beatrice Crona, Per Olsson, Maria Tengö, and Olga Yudina. Appreciation is also extended to those people who assisted with this research project (Samantha Purdy, Joslyn Spurgeon, Steven Simpson, and Katie Vaughan). Financial support for this work is gratefully acknowledged from the Brock University Chancellor's Chair in Research Excellence, the Canadian Water Network, and the Social Sciences and Humanities Research Council of Canada.

\section{LITERATURE CITED}

Adger, W. N., S. Huq, K. Brown, D. Conway, and M. Hulme. 2003. Adaptation to climate change in the developing world. Progress in Development Studies 3(3):179-195.

Ansell, C., and A. Gash. 2008. Collaborative governance in theory and practice. Journal of Public Administration Research and Theory 18(4):543-571. 
Armitage, D. 2008. Governance and the commons in a multilevel world. International Journal of the Commons 2(1):7-32.

Armitage, D., F. Berkes, A. Dale, E. Kocho-Schellenberg, and E. Patton. 2011. Co-management and the co-production of knowledge: learning to adapt in Canada's Arctic. Global Environmental Change 21:995-1004. http://dx.doi.org/10.1016/ j.gloenvcha.2011.04.006

Armitage, D., R. de Loë, and R. Plummer. 2012. Environmental governance and its implications for conservation practice. Conservation Letters 5(4):245-255. http://dx.doi.org/10.1111/j.1755-263X.2012.00238.x

Armitage, D., M. Marschke, and R. Plummer. 2008. Adaptive co-management and the paradox of learning. Global Environmental Change 18(1):86-98. http://dx.doi.org/10.1016/ j.gloenvcha.2007.07.002

Armitage, D. R., R. Plummer, F. Berkes, R. I. Arthur, A. T. Charles, I. J. Davidson-Hunt, A. Diduck, N. C. Doubleday, D. S. Johnson, M. Marschke, P. McConney, E. W. Pinkerton, and E. K. Wollenberg. 2009. Adaptive co-management for socialecological complexity. Frontiers in Ecology and the Environment 7:95-102. http://dx.doi.org/10.1890/070089

Bäckstrand, K. 2003. Civic science for sustainability: reframing the role of experts, policy-makers and citizens in environmental governance. Global Environmental Politics 3 (4):24-41. http://dx.doi.org/10.1162/152638003322757916

Ballesteros, A., S. Nakhooda, J. Werksman, and K. Hurlburt. 2010. Power, responsibility, and accountability: re-thinking the legitimacy of institutions for climate finance. Final report. World Resources Institute, Washington, D.C., USA. [online] URL: http://www.wri.org/publication/power-responsibilityaccountability

Beisheim, M., and K. Dingwerth. 2008. Procedural legitimacy and private transnational governance. Are the good ones doing better? SFB Governance Working Paper No. 14, SFB Research Center, Berlin, Germany. [online] URL: http:// www.sfb-governance.de/publikationen/sfbgov_wp/wp14/wp14. pdf?1325771094

Bellamy, J. A., D. H. Walker, G. T. McDonald, and G. J. Syme. 2001. A systems approach to the evaluation of natural resource management initiatives. Journal of Environmental Management 63(4):407-423. http://dx.doi.org/10.1006/jema.2001.0493

Berkes, F. 2007. Adaptive co-management and complexity: exploring the many faces of comanagement. Pages 19-37 in D. Armitage, F. Berkes, and N. Doubleday, editors. Adaptive comanagement: collaboration, learning, and multilevel governance. University of British Columbia Press, Vancouver, British Columbia, Canada.

Berkes, F. 2009. Evolution of co-management: role of knowledge generation, bridging organizations and social learning. Journal of Environmental Management 90:1692-1702. http://dx.doi.org/10.1016/j.jenvman.2008.12.001

Berkes, F., D. Armitage, and N. Doubleday. 2007. Synthesis: adapting, innovating, evolving. Pages 308-327 in D. Armitage, F. Berkes, and N. Doubleday, editors. Adaptive comanagement: collaboration, learning, and multi-level governance. University of British Columbia Press, Vancouver, British Columbia, Canada.

Berkes, F., J. Colding, and C. Folke. 2003. Introduction. Pages 1-30 in F. Berkes, J. Colding, and C. Folke, editors. Navigating social-ecological systems: building resilience for complexity and change. Cambridge University Press, Cambridge, UK.

Berkes, F., and C. Folke, editors. 1998. Linking social and ecological systems: management practices and social mechanisms for building resilience. Cambridge University Press, Cambridge, UK.

Biermann, F., M. M. Betsill, J. Gupta, N. Kanie, L. Lebel, D. Liverman, H. Schroeder, and B. Siebenhüner, with contributions from K. Conca, L. da Costa Ferreira, B. Desai, S. Tay, and R. Zondervan. 2009. Earth system governance: people, places and the planet. Science and implementation plan of the earth system governance project. Earth System Governance Report 1, IHDP Report 20. The Earth System Governance Project (IHDP), Bonn, Germany.

Biermann, F., and P. Pattberg. 2008. Global environmental governance: taking stock, moving forward. Annual Review of Environment and Resources 33:277-294. http://dx.doi. org/10.1146/annurev.environ.33.050707.085733

Blackstock, K. L., and C. E. Carter. 2007. Operationalising sustainability science for a sustainability directive? Reflecting on three pilot projects. Geographical Journal 173(4):343-357. http://dx.doi.org/10.1111/j.1475-4959.2007.00258.x

Carlsson, L., and F. Berkes. 2005. Co-management: concepts and methodological implications. Journal of Environmental Management 75:65-76. http://dx.doi.org/10.1016/j.

jenvman.2004.11.008

Carpenter, S., B. Walker, J. M. Anderies, and N. Abel. 2001. From metaphor to measurement: resilience of what to what? Ecosystems 4:765-781. http://dx.doi.org/10.1007/s10021-001-0045-9

Cash, D. W., W. N. Adger, F. Berkes, P. Garden, L. Lebel, P. Olsson, L. Pritchard, and O. Young. 2006. Scale and crossscale dynamics: governance and information in a multilevel world. Ecology and Society 11(2): 8. [online] URL: http:// www.ecologyandsociety.org/vol11/iss2/art8/

Clark, W. C. 2001. Social learning. Pages 382-384 in A. S. Goudie and D. J. Cuff, editors. Encyclopedia of global change: environmental change and human society. Oxford University Press, Oxford, UK. 
Conley, A., and M. A. Moote. 2003. Evaluating collaborative natural resource management. Society \& Natural Resources 16(5):371-386. http://dx.doi.org/10.1080/08941920309181

Cortner, H. J. 2000. Making science relevant to environmental policy. Environmental Science \& Policy 3(1):21-30. http://dx. doi.org/10.1016/S1462-9011(99)00042-8

Cundill, G. 2010. Monitoring social learning processes in adaptive comanagement: three case studies from South Africa. Ecology and Society 15(3): 28. [online] URL: http://www. ecologyandsociety.org/vol15/iss3/art28/

Cundill, G., and C. Fabricius. 2010. Monitoring the governance dimension of natural resource co-management. Ecology and Society 15(1): 15. [online] URL: http://www. ecologyandsociety.org/vol15/iss1/art15/

de Loë, R., D. Armitage, R. Plummer, S. Davidson, and L. Moraru. 2009. From government to governance: a state-ofthe-art review of environmental governance. Final Report. Prepared for Alberta Environment, Environmental Stewardship, Environmental Relations. Rob de Loë Consulting Services, Guelph, Ontario, Canada. [online] URL: http://environment. gov.ab.ca/info/library/8187.pdf

de Loë, R. C., and H. Bjornlund. 2010. Governance and the challenges of water and food security. Pages 41-58 in $\mathrm{H}$. Bjornlund, editor. Incentives and instruments for sustainable irrigation. Wessex Institute of Technology Press, Southampton, UK. http://dx.doi.org/10.2495/978-1-84564-406-2/04

Dietz, T., E. Ostrom, and P. C. Stern. 2003. The struggle to govern the commons. Science 302(5652):1907-1912. http:// dx.doi.org/10.1126/science.1091015

Dixon-Woods, M., S. Bonas, A. Booth, D. R. Jones, T. Miller, A. J. Sutton, R. L. Shaw, J. A. Smith, and B. Young. 2006. How can systematic reviews incorporate qualitative research? A critical perspective. Qualitative Research 6(1):27-44. http:// dx.doi.org/10.1177/1468794106058867

Duit, A., and V. Galaz. 2008. Governance and complexityemerging issues for governance theory. Governance 21 (3):311-335. http://dx.doi.org/10.1111/j.1468-0491.2008.00402. $\underline{\mathrm{X}}$

Engle, N. L., and M. C. Lemos. 2010. Unpacking governance: building capacity to climate change of river basins in Brazil. Global Environmental Change 20(1):4-13. http://dx.doi. org/10.1016/j.gloenvcha.2009.07.001

Fabricius, C., and S. Collins. 2007. Community-based natural resource management: governing the commons. Water Policy 9(2):83-97.

Fabricius, C., and G. Cundill. 2010. Building adaptive capacity in systems beyond the threshold: the story of Macubeni, South Africa. Pages 43-68 in R. Plummer and D. Armitage, editors.
Adaptive capacity and environmental governance. Springer, New York, New York, USA. http://dx.doi.org/10.1007/978-$\underline{3-642-12194-43}$

Fisher, R., R. Prabhu, and C. McDougall, editors. 2007. Adaptive collaborative management of community forests in Asia: experiences from Nepal, Indonesia and the Philippines. Center for International Forestry Research, Bogor, Indonesia. [online] URL: www.cifor.org/nc/online-library/browse/viewpublication/publication/2350.html

Folke, C. 2006. Resilience: the emergence of a perspective for social-ecological systems analyses. Global Environmental Change 16(3):253-67. http://dx.doi.org/10.1016/j.

gloenvcha.2006.04.002

Folke, C., S. Carpenter, T. Elmqvist, L. Gunderson, C. S. Holling, B. Walker, J. Bengtsson, F. Berkes, J. Colding, K. Danell, M. Falkenmark, M. Moberg, L. Gordon, R. Kaspersson, N. Kautsky, A. Kinzig, S. A. Levin, K. G. Mäler, L. Ohlsson, P. Olsson, E. Ostrom, W. Reid, J. Rockstöm, S. Savenije, and U. Svedin. 2002. Resilience and sustainable development: building adaptive capacity in a world of transformations. Report for the Swedish Environmental Advisory Council Ministry of the Environment, Stockholm, Sweden.

Folke, C., T. Hahn, P. Olsson, and J. Norberg. 2005. Adaptive governance of social-ecological systems. Annual Review of Environment and Resources 30:441-473. http://dx.doi. org/10.1146/annurev.energy.30.050504.144511

Galaz, V., P. Olsson, T. Hahn, C. Folke, and U. Svedin. 2006. The problem of fit between ecosystems and governance systems: insights and emerging challenges. Institutional Dimensions of Global Environmental Change (IDGEC) Synthesis Conference, 6-9 December 2006. Bali, Indonesia.

Galaz, V., P. Olsson, T. Hahn, C. Folke, and U. Svedin. 2008. The problem of fit among biophysical systems, environmental and resource regimes, and broader governance systems: insights and emerging challenges. Pages 147-182 in O. R. Young, L. A. King, and H. Schroeder, editors. Institutions and environmental change: principal findings, applications, and research frontiers. MIT Press, Boston, Massachusetts, USA.

Garaway, C. J., and R. I. Arthur. 2004. Adaptive learning: a practical framework for the implementation of adaptive comanagement: lessons from selected experiences in South and Southeast Asia. MRAG, London, UK. [online] URL: library. enaca.org/mangrove/publications/Adaptive L guidelines.pdf.

Gibson, R. B., S. Holtz, J. Tansey, G. Whitelaw, and S. Hassan. 2005. Sustainability assessment: criteria and process. Earthscan, London, UK.

Gibson, C. C., E. Ostrom, and T. K. Ahn. 2000. The concept of scale and the human dimensions of global change: a survey. 
Ecological Economics 32(2):217-239. http://dx.doi.org/10.1016/ $\underline{\text { S0921-8009(99)00092-0 }}$

Glasbergen, P. 1998. The question of environmental governance. Pages 1-18 in P. Glasbergen, editor. Co-operative environmental governance: public-private agreements as a policy strategy. Kluwer Academic, Dordrecht, the Netherlands. http://dx.doi.org/10.1007/978-94-011-5143-6_1

Green, S. 2005. Systematic reviews and meta-analysis. Singapore Medical Journal 46(6):270-274.

Hahn, T. 2011. Self-organized governance networks for ecosystem management: who is accountable? Ecology and Society 16(2): 18. [online] URL: http://www.ecologyandsociety. org/vol16/iss2/art18/

Hahn, T., P. Olsson, C. Folke, and K. Johansson. 2006. Trustbuilding, knowledge generation and organizational innovations: the role of a bridging organization for adaptive comanagement of a wetland landscape around Kristianstad Sweden. Human Ecology 34(4):573-592. http://dx.doi. org/10.1007/s10745-006-9035-Z

Hempel, L. C. 1996. Environmental governance: the global challenge. Island Press, Washington, D.C., USA.

Hughes, N., S. J. Closs, and D. Clark. 2009. Experiencing cancer in old-age: a qualitative systematic review. Qualitative Health Research 19(8):1139-1153. http://dx.doi. org/10.1177/1049732309341715

Huitema, D., E. Mostert, W. Egas, S. Moellenkamp, C. PahlWostl, and R. Yalcin. 2009. Adaptive water governance: assessing the institutional prescriptions of adaptive (co-) management from a governance perspective and defining a research agenda. Ecology and Society 14(1): 26. [online] URL: http://www.ecologyandsociety.org/vol14/iss1/art26/

Kates, R., W. C. Clark, R. Corell, J. M. Hall, C. C. Jaeger, I. Lowe, J. J. McCarthy, H.-J. Schellnhuber, B. Bolin, N. M. Dickson, S. Faucheux, G. C. Gallopin, A. Gruebler, B. Huntley, J. Jager, N. S. Jodha, R. E. Kasperson, A. Mabogunje, P. Matson, H. Mooney, B. Moore III, T. O'Riordan, and U. Svedin. 2001. Sustainability science. Science 292 (5517):641-642. http://dx.doi.org/10.1126/science.1059386

Kofinas, G. P. 2009. Adaptive co-management in socialecological governance. Pages 77-101 in F. S. Chapin III, G. P. Kofinas, and C. Folke, editors. Principles of ecosystem stewardship. Springer, New York, New York, USA. http://dx. doi.org/10.1007/978-0-387-73033-2 4

Kooiman, J., editor. 1993. Modern governance: new government - society interactions. Sage, London, UK.

Kooiman, J., and M. Bavinck. 2005. The governance perspective. Pages 11-25 in J. Kooiman, M. Bavinck, S. Jentoft, and R. Pullin, editors. Fish for life: interactive governance for fisheries. Amsterdam University Press, Amsterdam, the Netherlands. http://dx.doi.org/10.5117/978$\underline{9053566862}$

Lebel, L., J. M. Anderies, B. Campbell, C. Folke, S. HatfieldDodds, T. P. Hughes, and J. Wilson. 2006. Governance and the capacity to manage resilience in regional social-ecological systems. Ecology and Society 11(1): 19. [online] URL: http:// www.ecologyandsociety.org/vol11/iss1/art19/

Lee, K. 1993. Compass and gyroscope: integrating science and politics for the environment. Island Press, Washington, D. C., USA.

Lemos, M. C., and A. Agrawal. 2006. Environmental governance. Annual Review of Environment and Resources 31:297-325. http://dx.doi.org/10.1146/annurev. energy.31.042605.135621

Lockwood, M., J. Davidson, A. Curtis, E. Stratford, and R. Griffith. 2010. Governance principles for natural resource management. Society and Natural Resources 23(10):986-1001. http://dx.doi.org/10.1080/08941920802178214

Ludwig, D. 2001. The era of management is over. Ecosystems 4(8):758-764. http://dx.doi.org/10.1007/s10021-001-0044-x

McCay, B., and J. Acheson, editors. 1987. The question of the commons. The culture and ecology of communal resources. University of Arizona Press, Tuscon, Arizona, USA.

McDougall, C. L. 2001. Learning to learn: research into adaptive and collaborative management of community forests. Journal of Forestry and Livelihoods 2(1):34-36.

Meadowcroft, J. 1998. Co-operative management regimes: a way forward? Pages 21-42 in P. Glasbergen, editor. Cooperative environmental governance. Kluwer Academic, Dordrecht, the Netherlands. http://dx.doi.org/10.1007/978-94-011-5143-6 2

Moss, T. 2007. Solving problems of 'fit' at the expense of problems of 'interplay'? The spatial reorganisation of water management following the EU Water Framework Directive. Pages 64-109 in P. P. Mollinga, A. Dixit, and K. Athukorala, editors. Integrated water resources management: global theory, emerging practice and local needs. Sage, New Delhi, India.

Muñoz-Erickson, T. A., B. Aguilar-González, M. R. R. Loeser, and T. D. Sisk. 2010. A framework to evaluate ecological and social outcomes of collaborative management: lessons from implementation with a northern Arizona collaborative group. Environmental Management 45:132-144. http://dx.doi.org/10.1007/s00267-009-9400-y

Nadasdy, P. 2007. Adaptive co-management and the gospel of resilience. Pages 208-227 in D. Armitage, F. Berkes, and N. Doubleday, editors. Adaptive co-management: collaboration, 
learning and multilevel governance. University of British Columbia Press, Vancouver, British Columbia, Canada.

O'Connell, R., and S. Downe. 2009. A metasynthesis of midwives' experience of hospital practice in publicly funded settings: compliance, resistance and authenticity. Health: An Interdisciplinary Journal for the Social Study of Health, Illness and Medicine 13(6):589-609. http://dx.doi.org/10.1177/1363459308341439

Olsson, P., C. Folke, and F. Berkes. 2004a. Adaptive comanagement for building resilience in social-ecological systems. Environmental Management 34(1):75-90. http://dx. doi.org/10.1007/s00267-003-0101-7

Olsson, P., C. Folke, and T. Hahn. 2004b. Social-ecological transformation for ecosystem management: the development of adaptive co-management of a wetland landscape in southern Sweden. Ecology and Society 9(4): 2. [online] URL: http:// www.ecologyandsociety.org/vol9/iss4/art2

Ostrom, E. 2007. A diagnostic approach for going beyond panaceas. Proceedings of the National Academy of Sciences of the United States of America 104(39):15181-15187. http:// dx.doi.org/10.1073/pnas.0702288104

Ostrom, E., T. Dietz, N. Dolšak, P. C. Stern, S. Stonich, and E. U. Weber, editors. 2002. The drama of the commons. National Academy Press, Washington, D.C., USA.

Paavola, J. 2007. Institutions and environmental governance: a reconceptualization. Ecological Economics 63(1):93-103. http://dx.doi.org/10.1016/j.ecolecon.2006.09.026

Pahl-Wostl, C., J. Gupta, and D. Petry. 2008. Governance and the global water system: a theoretical exploration. Global Governance 14(4):419-435.

Petticrew, M., and H. Roberts. 2006. Systematic reviews in the social sciences: a practical guide. Blackwell, Malden, Massachusetts, USA. http://dx.doi.org/10.1002/9780470754887

Pinkerton, E., editor. 1989. Co-operative management of local fisheries. University of British Columbia Press, Vancouver, British Columbia, Canada.

Plummer, R. 2009. The adaptive co-management process: an initial synthesis of representative models and influential variables. Ecology and Society 14(2): 24. [online] URL: http:// www.ecologyandsociety.org/vol14/iss2/art24/

Plummer, R., and D. Armitage. 2007. A resilience-based framework for evaluating adaptive co-management: linking ecology, economics and society in a complex world. Ecological Economics 61:62-74. http://dx.doi.org/10.1016/j. ecolecon.2006.09.025

Plummer, R., and D. Armitage. 2010. Integrating perspectives on adaptive capacity and environmental governance. Pages 1-19 in D. Armitage and R. Plummer, editors. Adaptive capacity and environmental governance. Springer-Verlag, Berlin, Germany. http://dx.doi.org/10.1007/978-3-642-12194-4 1

Plummer, R., B. Crona, D. Armitage, P. Olsson, M. Tengö, and O. Yudina. 2012. Adaptive comanagement: a systematic review and analysis. Ecology and Society 17(3): 11. http://dx. doi.org/10.5751/ES-04952-170311

Plummer, R., and J. E. FitzGibbon. 2007. Connecting adaptive co-management, social learning and social capital through theory and practice. Pages 38-61 in D. Armitage, F. Berkes, and N. Doubleday, editors. Adaptive co-management: collaboration, learning and multilevel governance. University of British Columbia Press, Vancouver, British Columbia, Canada.

Reed, M. G., and S. Bruyneel. 2010. Rescaling environmental governance, rethinking the state: a three-dimensional review. Progress in Human Geography 34(5):646-653. http://dx.doi. org/10.1177/0309132509354836

Savan, B., C. Gore, and A. J. Morgan. 2004. Shifts in environmental governance in Canada: how are citizen environment groups to respond? Environment and Planning C: Government and Policy 22(4):605-619.

Singleton, S. 2002. Collaborative environmental planning in the west: the good, the bad and the ugly. Environmental Politics 11(3):54-75. http://dx.doi.org/10.1080/714000626

Suchman, M. 1995. Managing legitimacy: strategic and institutional approaches. Academy of Management Review 20 (3):571-610.

Thorne, S., L. Jensen, M. H. Kearney, G. Nobit, and M. Sandelowski. 2004. Qualitative meta-synthesis: reflections on methodological orientation and ideological agenda. Qualitative Health Research 14(10):1342-1365. http://dx.doi. org/10.1177/1049732304269888

Trachtenberg, Z., and W. Focht. 2005. Legitimacy and watershed collaborations: the role of public participation. Pages 53-82 in P. A. Sabatier, W. Focht, M. Lubell, Z. Trachtenberg, A. Vedlitz, and M. Matlock, editors. Swimming upstream: collaborative approaches to watershed management. MIT Press, Cambridge, Massachusetts, USA.

Tyler, T. R. 2006. Psychological perspectives on legitimacy and legitimation. Annual Review of Psychology 57:375-400. http://dx.doi.org/10.1146/annurev.psych.57.102904.190038

Van Kersbergen, K., and F. Van Waarden. 2004. 'Governance' as a bridge between disciplines: cross-disciplinary inspiration regarding shifts in governance and problems of governability, accountability and legitimacy. European Journal of Political Research 43:143-171. http://dx.doi.org/10.1111/ j.1475-6765.2004.00149.x 
Walters, C. J. 1986. Adaptive management of renewable resources. Macmillan, New York, New York, USA.

Westley, F. 2002. The devil in the dynamics: adaptive management on the front lines. Chapter 13 in L. H. Gunderson and C. S. Holling, editors. Panarchy: understanding transformations in human and natural systems. Island Press, Washington, D.C., USA.

Wollenberg, E., R. Iwan, G. Limberg, M. Moeliono, S. Rhee, and M. Sudana. 2007. Facilitating cooperation during times of chaos: spontaneous orders and muddling through in Malinau District, Indonesia. Ecology and Society 12(1): 3. [online] URL: http://www.ecologyandsociety.org/vol12/iss1/ $\underline{\operatorname{art} 3 /}$

World Commission on Environment and Development. 1987. Report of the world commission on environment and development: our common future. Published as annex to general assembly document A/42/427. [online] URL: http:// www.un-documents.net/our-common-future.pdf

World Resources Institute. 2003. World resources: 2002-2004. Decisions for the earth: balance, voice and power. World Resources Institute, Washington, D.C., USA.

Wyckhuys, K. A. G., and R. J. O’Neil. 2010. Social and ecological facets of pest management in Honduran subsistence agriculture: implications for IPM extension and natural resource management. Environment, Development and Sustainability 12:297-311. http://dx.doi.org/10.1007/

s10668-009-9195-2

Young, O. R., L. A. King, and H. Schroeder, editors. 2008. The institutional dimensions of global environmental change: principal findings and future directions. MIT Press, Boston, Massachusetts, USA. 